REVIEW

\title{
Osteoblasts in osteoporosis: past, emerging, and future anabolic targets
}

\author{
Pierre J Marie ${ }^{1,2}$ and Moustapha Kassem ${ }^{3,4}$ \\ ${ }^{1}$ Laboratory of Osteoblast Biology and Pathology, INSERM, U606, Hospital Lariboisiere, 2 Rue Ambroise Pare, 75475 Paris cedex 10, France, \\ ${ }^{2}$ University Paris Diderot, UMR606, F-75475 Paris, France, ${ }^{3}$ Department of Endocrinology and Metabolism, University Hospital of Odense, \\ DK-5000 Odense, Denmark and ${ }^{4}$ Stem Cell Unit, Department of Anatomy, College of Medicine, King Saud University, Riyadh, Saudi Arabia \\ (Correspondence should be addressed to P J Marie; Email: pierre.marie@inserm.fr)
}

\begin{abstract}
Objective: Age-related bone loss is associated with significant changes in bone remodeling characterized by decreased trabecular and periosteal bone formation relative to bone resorption, resulting in bone fragility and increased risk of fractures. Prevention or reversal of age-related decrease in bone mass and increase in bone fragility has been based on inhibition of bone resorption using anticatabolic drugs. The current challenge is to promote osteoblastogenesis and bone formation to prevent age-related bone deterioration. Methods: A limited number of approved therapeutic molecules are available to activate bone formation. Therefore, there is a need for anabolic drugs that promote bone matrix apposition at the endosteal, endocortical, and periosteal envelopes by increasing the number of osteoblast precursor cells and/or the function of mature osteoblasts. In this study, we review current therapeutics promoting bone formation and anabolic molecules targeting signaling pathways involved in osteoblastogenesis, based on selected full-text articles searched on Medline search from 1990 to 2010.

Results and discussion: We present current therapeutic approaches focused on intermittent parathyroid hormone and Wnt signaling agonists/antagonists. We also discuss novel approaches for prevention and treatment of defective bone formation and bone loss associated with aging and osteoporosis. These strategies targeting osteoblastic cell functions may prove to be useful in promoting bone formation and improving bone strength in the aging population.
\end{abstract}

European Journal of Endocrinology 165 1-10

\section{Introduction}

Bone remodeling is a physiological process that maintains the integrity of the skeleton by removing old bone and replacing it with a young matrix. During aging, the rate of bone turnover (i.e. activation frequency) increases in both genders, and at the tissue level, there is an impaired osteoblastic bone formation compared with osteoclastic bone resorption caused by decreased number and activity of individual osteoblastic cells $(1,2)$. The impaired osteoblastic bone formation with age translates into decreased newly formed trabecular bone, as shown by reduced mean wall thickness. The age-related osteoblast dysfunctions may be caused by extrinsic mechanisms that are mediated by age-related changes in bone microenvironment, such as changes in levels of hormones and growth factors, and intrinsic mechanisms caused by osteoblast cellular senescence (2-4). As a consequence, both trabecular and periosteal bone formation decline with age in males and females (5). The age-related progressive bone loss is exaggerated in patients with osteoporosis, a disease characterized by decreased bone mass, increased bone fragility, and increased risk of fractures (1).

Based on the observation that bone loss during aging results from an imbalance between bone resorption and bone formation, potent anticatabolic drugs that include estrogen, SERMS, amino-bisphosphonates, and RANKL-inhibitor have been the main therapies for osteoporosis. These drugs reduce bone resorption and secondarily bone formation due to the coupling phenomenon during bone remodeling and thus maintain bone mass (6). Although anticatabolics are efficient in stabilizing bone mass, there is a need for anabolic drugs that target osteoblastic cells to increase bone formation and bone strength (7). In this study, we review the current limited number of anabolic drugs as well as novel therapies for targeting specific signaling pathways involved in osteoblast differentiation and function.

\section{Osteoblastic cells and bone formation}

Bone formation is dependent on the recruitment of sufficient number of osteoblasts as well as the activity of 
individual osteoblasts. Osteoblastic cells are recruited to bone forming surfaces mainly from a group of skeletal stem cells with osteogenic differentiation potential (referred to as skeletal, mesenchymal stem cells (MSC), or stromal stem cells). Although the exact location of MSC in vivo is still in debate, recent evidence suggests that some of these cells are pericytes located on the outer surface of blood vessels and sinusoids in the bone marrow (8). Also, recent studies suggest that MSC reach bone surfaces from the circulation through vascular channels in association with bone remodeling sites (9). Once they arrive at the bone surface, osteoblastic cells produce bone matrix that becomes mineralized. Finally, osteoblasts die by apoptosis or become embedded in bone matrix as osteocytes. The anabolic therapies can increase bone formation by increasing the number or activity of MSC and mature osteoblasts or by preventing their apoptosis.

\section{Past anabolic therapy}

Sodium fluoride (NaF) was the first agent to show a dramatic effect on bone formation and bone mass in osteoporosis. NaF increases osteoblast number and matrix deposition $(10,11)$ through inhibition of a fluoride-sensitive phosphotyrosine phosphatase resulting in a sustained activation of the MAPK mitogenic signaling pathway (12). Also, treatment with $\mathrm{NaF}$ was shown to increase osteoblast number and bone formation in ovariectomized (OVX) rats (13) and osteoporotic patients $(14,15)$. However, treatment with $\mathrm{NaF}$ did not reduce fracture risk in patients with osteoporosis despite marked increase in vertebral bone mineral density and thus was dismissed as a useful drug for osteoporosis $(15,16)$. Discrepancy in the biological effects of $\mathrm{NaF}$ on bone mass and bone strength is caused by the accumulation of abnormal and unmineralized matrix $(17,18)$. These first therapeutic attempts to promote bone formation demonstrated that an efficient anabolic drug should not only increase the amount of bone matrix but also enhance the bone quality (microarchitecture and matrix mineralization).

\section{Present anabolic therapies}

Parathyroid hormone (PTH) is the only approved anabolic therapy for osteoporosis. Its use is based on the seminal finding that intermittent (and not sustained) low-dose PTH increases bone formation more than bone resorption, leading to increased bone mass. At the tissue level, intermittent PTH administration increases the number and activity of osteoblasts, enhances the mean wall thickness and trabecular bone volume, and improves bone microarchitecture by establishing trabecular connectivity and increasing cortical thickness (19). The anabolic effects of PTH on bone formation are mediated through PTH receptor-dependent mechanisms. PTH enhances osteoblastic cell proliferation and function, extends mature osteoblast life span through antiapoptotic effects, enhances Wnt signaling through inhibition of Wnt antagonist sclerostin, and enhances the local production of bone anabolic growth factors such as insulin-like growth factor 1 (IGF1) (20). Also, PTH improves the functional abilities of aged osteoblastic cells in mice by antagonizing the ageassociated increase in oxidative stress in osteoblastic cells (21). Clinical studies have demonstrated beneficial effects of intermittent PTH therapy on increasing bone mass and diminishing bone fragility associated with osteoporosis resulting from aging, sex hormone deficiency, and glucocorticoids therapy (22). One of the potential side effects of anabolic therapy with $\mathrm{PTH}$ is the over-stimulation of osteoblastic cells with a potential risk for developing osteosarcoma, as reported in long-term PTH therapy in rodents. However, human data do not support this hypothesis (23).

An alternative approach to promote bone formation is to stimulate endogenous PTH secretion using oral calcium-sensing receptor (CaSR) antagonists (calcilytics) that antagonize the parathyroid cell calcium CaSR, thereby stimulating the endogenous release of PTH (24). In aged OVX rats with established osteopenia, a calcilytic molecule was shown to increase PTH secretion and bone mass in the presence of an antiresorptive agent (25). Recently, an orally active CaSR antagonist was shown to increase bone formation and bone strength in OVX rats (26). Thus, calcilytic molecules may prove to be useful in promoting bone formation in osteopenic disorders. The clinical efficiency of CaSR antagonists in increasing bone mass and decreasing bone fragility compared with exogenous PTH therapy remains to be determined in humans.

Interestingly, strontium ranelate, an approved antiosteoporotic drug, (27-29) was found to activate the CaSR in osteoblasts (30), resulting in activation of osteoblastic cell replication, differentiation, and survival $(31,32)$. In OVX rats, strontium ranelate-treated animals exhibited increased bone formation and decreased bone resorption, resulting in prevention of trabecular bone loss, improved bone microarchitecture, and strength $(33,34)$. In postmenopausal osteoporotic women, strontium ranelate treatment increased bone mineral apposition rate and improved trabecular microarchitecture (35), which was associated with reduced fracture risk $(27,29)$. Thus, specific activation of the CaSR in bone cells may be efficient to increase bone mass and strength independently of changes in PTH secretion.

\section{Therapies in pipeline}

\section{Targeting Wnt signaling}

Wnt/ $\beta$-catenin signaling in bone is one of the main mechanisms controlling bone formation and bone 
mass (36). Several genetic studies indicate that LRP5/Wnt signaling pathway is anabolic for bone $(37,38)$. In vitro and in vivo studies showed that activation of the canonical Wnt/ $\beta$-catenin pathway promotes osteoblastic cell proliferation or differentiation and reduces adipogenic differentiation in $\operatorname{MSC}(39,40)$. In addition, Wnt signaling promotes osteoblast survival (41) and interacts with bone morphogenetic protein 2 (BMP2) (42) and PTH signaling (43) to increase osteoblastogenesis. Also, changes in Wnt signaling contribute to age-related bone loss in mice (44). Mechanical loading upregulates Wnt signaling in MSC (45), suggesting that the combination of reduced $\beta$-catenin signaling and decreased mechanical stimulation with age may contribute to the age-related decline in bone formation. The important role of Wnt signaling in the control of bone formation suggests that this pathway may be a potential therapeutic target. Accordingly, activation of the canonical Wnt signaling using glycogen synthase kinase 3 inhibitors results in enhanced bone formation and increased trabecular and cortical bone density and bone strength in aged or OVX osteopenic mice $(46,47)$. Although targeting the Wnt pathway may be a promising approach to promote bone formation, the therapeutic use of Wnt signaling agonists in clinical settings is limited due to the ubiquitous role of Wnt signaling. Given the potential implication of excessive Wnt signaling in cancer development, indirect targeting of Wnt signaling would be more specific and safe (48). An indirect approach is to inhibit Wnt antagonists. Sclerostin, the product of the SOST gene expressed by mature osteocytes, is a physiological negative modulator of bone formation $(49,50)$. Sclerostin binds only weakly to BMPs and acts by antagonizing Wnt binding to LRP4- 6 co-receptors $(51,52)$. The pre-clinical observation that loss-of-function mutation of sclerostin results in increased bone formation and bone mass (53) led to the interesting concept that targeting sclerostin may increase bone formation in vivo (54). Systemic injections of an antisclerostin MAB led to increase bone formation, bone mass, and strength in monkeys and OVX rats (55) and to increase bone formation markers in postmenopausal women (56). Therefore, it is envisaged that this strategy for targeting Wnt signaling may be efficient in increasing bone formation and bone mass in humans.

Besides sclerostin, other Wnt antagonists such as DKK 1 could be targeted to promote bone formation. The observations that mice lacking DKK1 show increased bone formation and bone mass (57) whereas mice overexpressing DKK1 in osteoblasts are osteopenic (58) suggest that pharmacological DKK1 antagonists may increase bone formation and bone mass. sFRP1, another Wnt antagonist that acts by binding Wnt proteins, (59) could also be targeted because overexpression of sFRP1 inhibits bone formation whereas deletion of sFRP1 increases bone mass in mice (60). Oncostatin may also be targeted to promote bone formation because this cytokine produced by osteoblasts and osteocytes promotes bone formation via activation of leukemia inhibitory factor receptor and decreased sclerostin production (61). Recent data indicate that LRP5 may not play a major role in osteoblasts and that bone mass is rather regulated by Wnt-independent effects of LRP5 on gut-derived serotonin. Pharmacological inhibition of gut-derived serotonin promotes bone formation and prevents bone loss in OVX mice $(62,63)$. If confirmed, these findings may possibly provide a novel therapeutic approach in osteoporosis therapy, in addition to target LRP5/6 in osteoblasts for promoting bone formation in osteopenic disorders (64).

\section{Future anabolic therapies}

A large number of studies in the recent years have identified a number of potential pathways that can be targeted to increase bone formation and bone mass (Table 1 and Fig. 1). However, only few of them appear to be suitable and safe for long-term systemic therapy due to low specificity, non-skeletal effects, potential side effects, and cost.

\section{Statin-like molecules}

Statins are inhibitors of the enzyme 3-hydroxy-3methylglutaryl coenzyme A reductase, which is involved in the biosynthesis of cholesterol and is used clinically to treat hypercholesterolemia. Statins have been identified as enhancers of the BMP2 gene expression and bone formation in vivo during drug screen for bone anabolic agents (65). Further studies have demonstrated that statins can stimulate vascular endothelial growth factor (VEGF) expression in osteoblasts via reduced protein prenylation, thus promoting osteoblastic differentiation (66). Statins can also enhance fracture healing in animal models (67). The clinical effects of statins on bone in humans have been studied in a number of case-control studies. In some studies, use of statins was associated with increased bone mass and decreased fracture risk in postmenopausal women $(68,69)$, whereas in others, these effects

Table 1 Comparative effectiveness of past and present approaches targeting bone formation in preclinical or clinical studies.

\begin{tabular}{lcccc}
\hline & $\begin{array}{c}\text { Osteoblast } \\
\text { number }\end{array}$ & $\begin{array}{c}\text { Bone } \\
\text { formation }\end{array}$ & $\begin{array}{c}\text { Bone } \\
\text { volume }\end{array}$ & $\begin{array}{c}\text { Bone } \\
\text { strength }\end{array}$ \\
\hline Fluoride & + & + & + & - \\
Statins & + & + & + & \pm \\
PTH & ++ & ++ & ++ & ++ \\
SrRan & + & + & + & + \\
Calcilytics & + & + & + & $?$ \\
Antisclerostin & ++ & ++ & ++ & ++ \\
\hline
\end{tabular}

++ , indicates a huge positive effect; + , indicates a positive effect; \pm , indicates a variable effect; - , indicates no detectable effect; ?, indicates unknown effect. The reader is referred to the text for more details. 


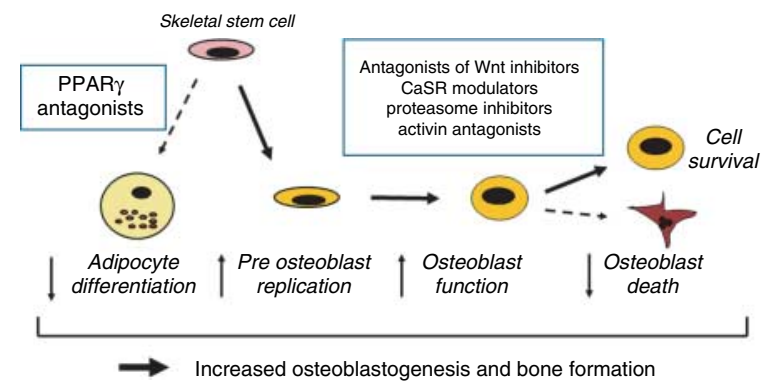

Figure 1 Potential anabolic molecules targeted to the osteoblast. With age, osteoblast number decreases due to preferential adipogenic differentiation of mesenchymal stromal cells, decreased preosteoblast replication and function, and increased death of more mature osteoblasts. Several molecules may potentially promote osteoblastogenesis by reducing adipogenic differentiation of mesenchymal stromal cells, enhancing preosteoblast replication or function, or increasing osteoblast survival.

were not reproducible $(70,71)$. A limitation of the use of available statins as bone forming agents is that the dose needed to enhance bone formation is much higher than that needed to reduce blood cholesterol levels. Thus, there is a need for developing more potent and preferably bone-specific statin-related molecules.

\section{Growth factors}

During the recent years, several growth factors with positive effects on osteoblastic cells and bone mass have been identified. Although in theory growth factors are possible candidates to increase bone formation, their clinical use is limited due to their systemic non-skeletal effects. Among these factors, BMPs have long been recognized for their ability to enhance differentiation of skeletal stem cells into osteoblastic cells. In vivo, BMP induce formation of significant amount of bone and cartilage when implanted subcutaneously or intramusculary and to increase both endosteal and periosteal bone formation $(72,73)$. Among the BMPs, recombinant human BMP2 and BMP7 are approved for clinical use in orthopedic surgery for cases of long bone nonunion fractures and acute tibial fractures treated with intramedullary fixation. However, several off-label uses have been reported including spinal fusion in place of iliac crest bone graft. The clinical use of BMP for treating systemic diseases like osteoporosis is more complex. Only one BMP member, BMP6, has been demonstrated to promote bone formation and to restore bone mass in aged OVX rats (74). Following systemic injections, BMPs have a short half-life and the dose required is expensive. Thus, BMPs may have limited use as systemic anabolic therapies and small molecules inducers of BMP such as statins (see above) may be a more appropriate approach.

Another bone growth factor that is a member of BMP family is transforming growth factor $\beta$ (TGF $\beta$ or TGFB1) that promotes osteoblastic cell proliferation, function, and survival (75). In vivo, TGF $\beta$ does not prevent bone loss induced by ovariectomy (76) but prevents immobilization-related bone loss caused by decreased osteoblastogenesis $(77,78)$. Inhibins (Inh), activins, and myostatins (GDF8) are other members of the TGF $\beta$ superfamily that control bone metabolism (79). InhA overexpression was found to prevent gonadectomyinduced bone loss (80). Activin modulates osteogenic differentiation via binding to activin receptors $(80,81)$. Interestingly, a soluble form of activin receptor type IIA, which acts as an activin antagonist, was shown to increase bone formation, bone mass, and strength in OVX mice and non-human primates $(82,83)$. Furthermore, mice lacking GDF8, which binds to activin receptor type IIB and antagonizes osteogenic differentiation, show increased bone mineral density, suggesting that the development of GDF8 antagonists may promote bone formation in vivo $(84,85)$. Other growth factors may be candidates for use as bone anabolic factors. Epidermal growth factor (EGF) and platelet-derived growth factor (PDGF) are potent mitogenic factors for osteoblast progenitor cells in vitro $(86,87)$ and in vivo. In normal rats, EGF administration promotes periosteal bone formation (88). In OVX rats, PDGF administration increases osteoblast number, resulting in increased bone mass and strength (89). Fibroblast growth factors (FGFs) are other positive regulators of osteoblastogenesis (90), and systemic administration of FGF2 was found to increase bone formation and bone strength in OVX rats $(91,92)$. VEGF can also promote bone formation in vivo (93). However, all the above-mentioned growth factors, despite their potent anabolic effects on bone formation, exert systemic pleiotropic effects and thus may not be suitable in their current forms as systemic therapeutics.

Both GH and IGF1 are considered potential anabolic agents because they play physiological roles in bone mass acquisition and maintenance $(94,95)$. The levels of GH, IGF1, and some IGF binding proteins (IGFBPs) that regulate IGF activity decrease with age in elderly $(96,97)$ and in osteoporotic subjects $(98,99)$. A role of IGF/IGFBP signaling in age-related bone loss is supported by the finding that high levels of IGFBP2 correlate with increased bone turnover in aged men and women (100). Although GH promotes osteoblastic cell proliferation and differentiation (101), its effects on osteoblasts are mainly mediated by IGF1 (102). Genetic models in mice indicate that endogenous IGF1 increases bone formation and bone mass, which is more significant at the cortical than at the trabecular bone level $(103,104)$. Consistently, reduction in serum IGF1 levels results in decreased subperiosteal expansion and bone strength (105). In vivo treatment with IGF1 stimulates bone formation (106). However, IGF1 administration only partially restores the deficit in the expression of osteoblast markers in aging animals (107), possibly because aging induces receptormediated skeletal resistance to IGF1 (108). In animal models of osteoporosis, systemic administration of 
IGF1 or IGF2/IGFBP2 promotes bone formation and prevents bone loss (109-111). Clinical trials revealed an increase in bone mineral density in some elderly normal and osteoporotic patients treated with low doses of GH or IGF1 (112-114). The potential use of GH or IGF1 as therapy for age-related bone loss is, however, uncertain given their stimulatory effect on bone resorption, which may compromise their positive effect on bone formation (115). Moreover, GH therapy cannot be easily used in patients with osteoporosis because of possible side effects and potential stimulation of growth of latent cancer.

\section{Other potential targets for anabolic therapies}

There are multiple other potential alternative approaches for increasing bone formation (Fig. 1). A theoretical approach is to inhibit marrow adipogenesis with the aim of concomitantly increasing osteoblastogenesis and bone formation. Several pharmacological agents act on bone marrow MSC to favor osteoblastogenesis and decrease adipogenesis, but these agents may also impact on other tissues (116). Non-pharmacological ways to positively influence MSC differentiation toward osteoblasts include the use of low-magnitude mechanical signals (117) and targeting signals that control MSC plasticity $(118,119)$. For example, inactivation of the master adipocyte transcription factor Ppary (Pparg) in mice results in inhibition of adipogenesis and increased bone formation and bone mass (120). Another possible target is the cannabinoid receptor type 1 (CB1 or CNR1) that contributes to age-related bone loss through its effects on MSC differentiation. CB1 deficiency in aging mice leads to increased adipogenesis and defective bone formation, suggesting that CB1 agonists may promote bone formation and prevent age-related bone loss (121).

An alternative approach to promote bone formation is to antagonize molecules that inhibit bone formation. Aging is associated with increased serum tumor necrosis factor $\alpha(\mathrm{TNF} \alpha)$ levels (122). This cytokine inhibits bone formation in part by inducing osteoblast apoptosis (123). Consistently, TNF $\alpha$ antagonists were found to reverse the age-related deficit in bone formation (124). Another example is inhibition of the proline-rich tyrosine kinase 2 (PYK2 or PTK2B), a non-receptor tyrosine kinase expressed in bone cells. PYK2-deficient mice show high bone mass and increased MSC differentiation and bone formation, and inhibition of PYK2 was shown to prevent bone loss in OVX rats (125). It can also be considered to inhibit midkine, a heparin-binding growth factor, because midkine deficiency results in increased trabecular bone formation in mice (126).

An emerging potential therapy is to target the osteoblast proteasome. This approach is based on the observation that the proteasome inhibitor bortezomib had bone forming effects in multiple myeloma patients (127). Proteasome inhibitors can promote osteoblast differentiation in MSC via increased BMP2 expression and stabilization of RUNX2 and proteasome inhibition
(128-130). In support of this effect, treatment with the proteasome inhibitor bortezomib increased osteoblast differentiation, trabecular bone formation, and bone mass in normal and OVX mice (129). Other approaches can be used to promote BMP2 expression in osteoblastic cells. For example, oxytocin was reported to upregulate BMP2 expression, which in turns promotes bone formation (131). An oxytocin analog was found to promote bone formation and to reverse bone loss in OVX mice, suggesting that oxytocin may be a potential therapeutic agent (132). Despite the potential interest of these various approaches, further basic and clinical studies are needed to determine whether these strategies can lead to effective and safe therapies for preventing or treating the defective bone formation and bone loss associated with aging (Fig. 1).

Finally, we need to consider that the aging process per se involves a number of pathophysiological mechanisms that lead to the deterioration of osteoblastic functions and impaired bone formation $(3,4,133)$. This parallels the changes in many aspects in other cellular compartments in the aging organism. Thus, other medications that target the basic mechanisms of cellular aging may possibly be relevant for osteoporosis therapy (Fig. 1). Resveratrol is a small polyphenol identified as activator of sirtuin 1 (SIRT1), a member of a family of $\mathrm{NAD}^{+}$-dependent deacetylases and ADP-ribosyltransferases that underlies some of the antiaging effects of dietary restriction in mammals (134). Resveratrol-fed old mice show a reduction in aging features including prevention of age-related decreased bone mass (135). The positive effects of resveratrol on bone include enhanced in vitro osteoblast differentiation (136) and inhibition of adipocyte differentiation (137). Currently, SIRT1 agonists with much higher potency than resveratrol are being tested in clinical trials against type II diabetes. Depending on the initial results from clinical trials, this class of drugs may possibly have a role for preventing age-related bone loss in addition to other beneficial effects on the aging organism.

\section{Conclusion}

Aging is associated with impaired bone formation that is a principal pathogenetic mechanism mediating bone fragility in osteoporosis. Until recently, a limited number of approved therapeutic molecules capable of activating bone formation and increasing bone mass and strength has been available. Current promising approaches focus on agonists/antagonists of osteoblastic Wnt signaling pathways. Several other strategies, including therapeutics that target skeletal stem cells and osteoblastic cell functions, are being explored and may prove to be useful in promoting bone formation. It is hoped that providing more options for developing efficient therapeutic strategies targeting bone formation will allow prevention and restoration of age-related bone strength. 


\section{Declaration of interest}

The authors declare that there is no conflict of interest that could be perceived as prejudicing the impartiality of the research reported.

\section{Funding}

This research did not receive any specific grant from any funding agency in the public, commercial or not-for-profit sector.

\section{References}

1 Khosla S \& Riggs BL. Pathophysiology of age-related bone loss and osteoporosis. Endocrinology and Metabolism Clinics of North America 200534 1015-1030. (doi:10.1016/j.ecl.2005.07.009)

2 Manolagas SC \& Parfitt AM. What old means to bone. Trends in Endocrinology and Metabolism 201021 369-374. (doi:10.1016/j. tem.2010.01.010)

3 Kassem M \& Marie PJ. Senescence-associated intrinsic mechanisms of osteoblast dysfunctions. Aging Cell $2011 \mathbf{1 0}$ 191-197. (doi:10.1111/j.1474-9726.2011.00669.x)

4 Marie PJ \& Kassem M. Extrinsic mechanisms involved in agerelated defective bone formation. Journal of Clinical Endocrinology and Metabolism 201196 600-609. (doi:10.1210/jc.2010-2113)

5 Seeman E. Pathogenesis of bone fragility in women and men. Lancet 2002359 1841-1850. (doi:10.1016/S0140-6736(02) 08706-8)

6 Riggs BL \& Parfitt AM. Drugs used to treat osteoporosis: the critical need for a uniform nomenclature based on their action on bone remodeling. Journal of Bone and Mineral Research 200520 177-184. (doi:10.1359/JBMR.041114)

7 Khosla S, Westendorf JJ \& Oursler MJ. Building bone to reverse osteoporosis and repair fractures. Journal of Clinical Investigation 2008118 421-428. (doi:10.1172/JCI33612)

8 Sacchetti B, Funari A, Michienzi S, Di Cesare S, Piersanti S, Saggio I, Tagliafico E, Ferrari S, Robey PG, Riminucci M \& Bianco P. Self-renewing osteoprogenitors in bone marrow sinusoids can organize a hematopoietic microenvironment. Cell 2007131 324-336. (doi:10.1016/j.cell.2007.08.025)

9 Andersen TL, Sondergaard TE, Skorzynska KE, DagnaesHansen F, Plesner TL, Hauge EM, Plesner T \& Delaisse JM. A physical mechanism for coupling bone resorption and formation in adult human bone. American Journal of Pathology 2009 174 239-247. (doi:10.2353/ajpath.2009.080627)

10 Kassem M, Mosekilde L \& Eriksen EF. Effects of fluoride on human bone cells in vitro: differences in responsiveness between stromal osteoblast precursors and mature osteoblasts. European Journal of Endocrinology $1994130381-386$. (doi:10.1530/eje.0.1300381)

11 Marie PJ \& Hott M. Short-term effects of fluoride and strontium on bone formation and resorption in the mouse. Metabolism 198635 547-551. (doi:10.1016/0026-0495(86)90013-2)

12 Lau KH \& Baylink DJ. Osteoblastic tartrate-resistant acid phosphatase: its potential role in the molecular mechanism of osteogenic action of fluoride. Journal of Bone and Mineral Research 200318 1897-1900. (doi:10.1359/jbmr.2003.18.10.1897)

13 Modrowski D, Miravet L, Feuga M, Bannie F \& Marie PJ. Effect of fluoride on bone and bone cells in ovariectomized rats. Journal of Bone and Mineral Research 19927 961-969. (doi:10.1002/jbmr. 5650070813)

14 Marie PJ, De Vernejoul MC \& Lomri A. Stimulation of bone formation in osteoporosis patients treated with fluoride associated with increased DNA synthesis by osteoblastic cells in vitro. Journal of Bone and Mineral Research 19927 103-113. (doi:10. 1002/jbmr.5650070115)

15 Meunier PJ, Sebert JL, Reginster JY, Briancon D, Appelboom T, Netter P, Loeb G, Rouillon A, Barry S, Evreux JC, Avouac B \& Marchandise X. Fluoride salts are no better at preventing new vertebral fractures than calcium-vitamin D in postmenopausal osteoporosis: the FAVOStudy. Osteoporosis International $1998 \mathbf{8}$ 4-12. (doi:10.1007/s001980050041)

16 Riggs BL, Hodgson SF, O'Fallon WM, Chao EY, Wahner HW, Muhs JM, Cedel SL \& Melton LJ III. Effect of fluoride treatment on the fracture rate in postmenopausal women with osteoporosis. New England Journal of Medicine 1990322 802-809. (doi:10. 1056/NEJM199003223221203)

17 Balena R, Kleerekoper M, Foldes JA, Shih MS, Rao DS, Schober HC \& Parfitt AM. Effects of different regimens of sodium fluoride treatment for osteoporosis on the structure, remodeling and mineralization of bone. Osteoporosis International $1998 \mathbf{8}$ 428-435. (doi:10.1007/s001980050087)

18 Lundy MW, Stauffer M, Wergedal JE, Baylink DJ, Featherstone JD, Hodgson SF \& Riggs BL. Histomorphometric analysis of iliac crest bone biopsies in placebo-treated versus fluoride-treated subjects. Osteoporosis International $1995 \mathbf{5}$ 115-129. (doi:10.1007/ BF01623313)

19 Compston JE. Skeletal actions of intermittent parathyroid hormone: effects on bone remodelling and structure. Bone 200740 1447-1452. (doi:10.1016/j.bone.2006.09.008)

20 Jilka RL. Molecular and cellular mechanisms of the anabolic effect of intermittent PTH. Bone 200740 1434-1446. (doi:10. 1016/j.bone.2007.03.017)

21 Jilka RL, Almeida M, Ambrogini E, Han L, Roberson PK, Weinstein RS \& Manolagas SC. Decreased oxidative stress and greater bone anabolism in the aged, when compared to the young, murine skeleton with parathyroid hormone administration. Aging Cell 2010 9 851-867. (doi:10.1111/j.1474-9726. 2010.00616.x)

22 Hodsman AB, Bauer DC, Dempster DW, Dian L, Hanley DA, Harris ST, Kendler DL, McClung MR, Miller PD, Olszynski WP, Orwoll E \& Yuen CK. Parathyroid hormone and teriparatide for the treatment of osteoporosis: a review of the evidence and suggested guidelines for its use. Endocrine Reviews 200526 688-703. (doi:10.1210/er.2004-0006)

23 Subbiah V, Madsen VS, Raymond AK, Benjamin RS \& Ludwig JA. of mice and men: divergent risks of teriparatide-induced osteosarcoma. Osteoporosis International 201021 1041-1045. (doi:10.1007/s00198-009-1004-0)

24 Arey BJ, Seethala R, Ma Z, Fura A, Morin J, Swartz J, Vyas V, Yang W, Dickson JK Jr \& Feyen JH. A novel calcium-sensing receptor antagonist transiently stimulates parathyroid hormone secretion in vivo. Endocrinology 2005146 2015-2022. (doi:10. 1210/en.2004-1318)

25 Gowen M, Stroup GB, Dodds RA, James IE, Votta BJ, Smith BR, Bhatnagar PK, Lago AM, Callahan JF, DelMar EG, Miller MA, Nemeth EF \& Fox J. Antagonizing the parathyroid calcium receptor stimulates parathyroid hormone secretion and bone formation in osteopenic rats. Journal of Clinical Investigation 2000 105 1595-1604. (doi:10.1172/JCI9038)

26 Kumar S, Matheny CJ, Hoffman SJ, Marquis RW, Schultz M, Liang $X$, Vasko JA, Stroup GB, Vaden VR, Haley H, Fox J, DelMar EG, Nemeth EF, Lago AM, Callahan JF, Bhatnagar P, Huffman WF, Gowen M, Yi B, Danoff TM \& Fitzpatrick LA. An orally active calcium-sensing receptor antagonist that transiently increases plasma concentrations of PTH and stimulates bone formation. Bone $2010 \mathbf{4 6} 534-542$. (doi:10.1016/j.bone.2009. 09.028)

27 Meunier PJ, Roux C, Seeman E, Ortolani S, Badurski JE, Spector TD, Cannata J, Balogh A, Lemmel EM, Pors-Nielsen S, Rizzoli R, Genant HK \& Reginster JY. The effects of strontium ranelate on the risk of vertebral fracture in women with postmenopausal osteoporosis. New England Journal of Medicine 2004350 459-468. (doi:10.1056/NEJMoa022436)

28 Marie PJ. Strontium as therapy for osteoporosis. Current Opinion in Pharmacology 20055 633-636. (doi:10.1016/j.coph.2005. 05.005)

29 Reginster JY, Seeman E, De Vernejoul MC, Adami S, Compston J, Phenekos C, Devogelaer JP, Curiel MD, Sawicki A, Goemaere S, Sorensen OH, Felsenberg D \& Meunier PJ. Strontium ranelate 
reduces the risk of nonvertebral fractures in postmenopausal women with osteoporosis: treatment of peripheral osteoporosis (TROPOS) study. Journal of Clinical Endocrinology and Metabolism 200590 2816-2822. (doi:10.1210/jc.2004-1774)

30 Brown EM. Is the calcium receptor a molecular target for the actions of strontium on bone? Osteoporosis International $2003 \mathbf{1 4}$ (Supplement 3) S25-S34. (doi:10.1007/s00198-002-1346-6)

31 Brennan TC, Rybchyn MS, Green W, Atwa S, Conigrave AD \& Mason RS. Osteoblasts play key roles in the mechanisms of action of strontium ranelate. British Journal of Pharmacology 2009157 1291-1300. (doi:10.1111/j.1476-5381.2009.00305.x)

32 Fromigué O, Hay E, Barbara A, Petrel C, Traiffort E, Ruat M \& Marie PJ. Calcium sensing receptor-dependent and receptorindependent activation of osteoblast replication and survival by strontium ranelate. Journal of Cellular and Molecular Medicine 2009 13 2189-2199. (doi:10.1111/j.1582-4934.2008.00673.x)

33 Bain SD, Jerome C, Shen V, Dupin-Roger I \& Ammann P. Strontium ranelate improves bone strength in ovariectomized rat by positively influencing bone resistance determinants. Osteoporosis International 200920 1417-1428. (doi:10.1007/ s00198-008-0815-8)

34 Marie PJ, Hott M, Modrowski D, De Pollak C, Guillemain J, Deloffre P \& Tsouderos Y. An uncoupling agent containing strontium prevents bone loss by depressing bone resorption and maintaining bone formation in estrogen-deficient rats. Journal of Bone and Mineral Research 19938 607-615. (doi:10.1002/jbmr. 5650080512)

35 Arlot ME, Jiang Y, Genant HK, Zhao J, Burt-Pichat B, Roux JP, Delmas PD \& Meunier PJ. Histomorphometric and microCT analysis of bone biopsies from postmenopausal osteoporotic women treated with strontium ranelate. Journal of Bone and Mineral Research 200823 215-222. (doi:10.1359/jbmr. 071012)

36 Krishnan V, Bryant HU \& Macdougald OA. Regulation of bone mass by Wnt signaling. Journal of Clinical Investigation 2006116 1202-1209. (doi:10.1172/JCI28551)

37 Glass DA II \& Karsenty G. In vivo analysis of Wnt signaling in bone. Endocrinology 2007148 2630-2634. (doi:10.1210/en. 2006-1372)

38 Johnson ML, Harnish K, Nusse R \& Van Hul W. LRP5 and Wnt signaling: a union made for bone. Journal of Bone and Mineral Research 200419 1749-1757. (doi:10.1359/JBMR.040816)

39 Bodine PV \& Komm BS. Wnt signaling and osteoblastogenesis. Reviews in Endocrine and Metabolic Disorders 20067 33-39. (doi:10.1007/s11154-006-9002-4)

40 Qiu W, Andersen TE, Bollerslev J, Mandrup S, Abdallah BM \& Kassem M. Patients with high bone mass phenotype exhibit enhanced osteoblast differentiation and inhibition of adipogenesis of human mesenchymal stem cells. Journal of Bone and Mineral Research 200722 1720-1731. (doi:10.1359/jbmr. 070721)

41 Almeida M, Han L, Bellido T, Manolagas SC \& Kousteni S. Wnt proteins prevent apoptosis of both uncommitted osteoblast progenitors and differentiated osteoblasts by beta-catenindependent and -independent signaling cascades involving Src/ERK and phosphatidylinositol 3-kinase/AKT. Journal of Biological Chemistry 2005280 41342-41351. (doi:10.1074/ jbc.M502168200)

42 Rawadi G, Vayssiere B, Dunn F, Baron R \& Roman-Roman S. BMP-2 controls alkaline phosphatase expression and osteoblast mineralization by a Wnt autocrine loop. Journal of Bone and Mineral Research 200318 1842-1853. (doi:10.1359/jbmr. 2003.18.10.1842)

43 Kramer I, Keller H, Leupin O \& Kneissel M. Does osteocytic SOST suppression mediate PTH bone anabolism? Trends in Endocrinology and Metabolism 201021 237-244. (doi:10.1016/ j.tem.2009.12.002)

44 Manolagas SC \& Almeida M. Gone with the Wnts: beta-catenin, T-cell factor, forkhead box $\mathrm{O}$, and oxidative stress in age-dependent diseases of bone, lipid, and glucose metabolism. Molecular Endocrinology 200721 2605-2614. (doi:10.1210/me.20070259)

45 Robinson JA, Chatterjee-Kishore M, Yaworsky PJ, Cullen DM, Zhao W, Li C, Kharode Y, Sauter L, Babij P, Brown EL, Hill AA, Akhter MP, Johnson ML, Recker RR, Komm BS \& Bex FJ. Wnt/beta-catenin signaling is a normal physiological response to mechanical loading in bone. Journal of Biological Chemistry 2006 281 31720-31728. (doi:10.1074/jbc.M602308200)

46 Clement-Lacroix P, Ai M, Morvan F, Roman-Roman S, Vayssiere B, Belleville C, Estrera K, Warman ML, Baron R \& Rawadi G. Lrp5-independent activation of Wnt signaling by lithium chloride increases bone formation and bone mass in mice. PNAS 2005102 17406-17411. (doi:10.1073/pnas. 0505259102)

47 Kulkarni NH, Onyia JE, Zeng Q, Tian X, Liu M, Halladay DL, Frolik CA, Engler T, Wei T, Kriauciunas A, Martin TJ, Sato M, Bryant HU \& Ma YL. Orally bioavailable GSK-3alpha/beta dual inhibitor increases markers of cellular differentiation in vitro and bone mass in vivo. Journal of Bone and Mineral Research 200621 910-920. (doi:10.1359/jbmr.060316)

48 Enders GH. Wnt therapy for bone loss: golden goose or Trojan horse? Journal of Clinical Investigation 2009119 758-760. (doi:10.1172/JCI38973)

49 van Bezooijen RL, Svensson JP, Eefting D, Visser A, van der Horst G, Karperien M, Quax PHA, Vrieling H, Papapoulos SE, ten Dijke P \& Löwik CWGM. Wnt but not BMP signaling is involved in the inhibitory action of Sclerostin on BMP-stimulated bone formation. Journal of Bone and Mineral Research 200722 19-28. (doi:10.1359/ jbmr.061002)

50 Poole KE, van Bezooijen RL, Loveridge N, Hamersma H, Papapoulos SE, Lowik CW \& Reeve J. Sclerostin is a delayed secreted product of osteocytes that inhibits bone formation. FASEB Journal 200519 1842-1844. (doi:10.1096/fj.05-4221fje)

51 Choi HY, Dieckmann M, Herz J \& Niemeier A. Lrp4, a novel receptor for Dickkopf 1 and sclerostin, is expressed by osteoblasts and regulates bone growth and turnover in vivo. PLOS ONE 2009 4 e7930. (doi:10.1371/journal.pone.0007930)

52 Li X, Zhang Y, Kang H, Liu W, Liu P, Zhang J, Harris SE \& Wu D. Sclerostin binds to LRP $5 / 6$ and antagonizes canonical Wnt signaling. Journal of Biological Chemistry 2005280 19883-19887. (doi:10.1074/jbc.M413274200)

53 Li X, Ominsky MS, Niu QT, Sun N, Daugherty B, D'Agostin D, Kurahara C, Gao Y, Cao J, Gong J, Asuncion F, Barrero M, Warmington K, Dwyer D, Stolina M, Morony S, Sarosi I, Kostenuik PJ, Lacey DL, Simonet WS, Ke HZ \& Paszty C. Targeted deletion of the sclerostin gene in mice results in increased bone formation and bone strength. Journal of Bone and Mineral Research 200823 860-869. (doi:10.1359/jbmr.080216)

54 Paszty C, Turner CH \& Robinson MK. Sclerostin: a gem from the genome leads to bone-building antibodies. Journal of Bone and Mineral Research 201025 1897-1904. (doi:10.1002/jbmr.161)

55 Li X, Ominsky MS, Warmington KS, Morony S, Gong J, Cao J, Gao Y, Shalhoub V, Tipton B, Haldankar R, Chen Q, Winters A, Boone T, Geng Z, Niu QT, Ke HZ, Kostenuik PJ, Simonet WS, Lacey DL \& Paszty C. Sclerostin antibody treatment increases bone formation, bone mass, and bone strength in a rat model of postmenopausal osteoporosis. Journal of Bone and Mineral Research 200924 578-588. (doi:10.1359/jbmr.081206)

56 Padhi D, Jang G, Stouch B, Fang L \& Posvar E. Single-dose, placebo-controlled, randomized study of AMG 785, a sclerostin monoclonal antibody. Journal of Bone and Mineral Research 2011 26 19-26. (doi:10.1002/jbmr.173)

57 Morvan F, Boulukos K, Clément-Lacroix P, Roman Roman S, Suc-Royer I, Vayssière B, Ammann P, Martin P, Pinho S, Pognonec P, Mollat P, Niehrs C, Baron R \& Rawadi G. Deletion of a single allele of the Dkk1 gene leads to an increase in bone formation and bone mass. Journal of Bone and Mineral Research 200621 934-945. (doi:10.1359/jbmr.060311)

58 Guo J, Liu M, Yang D, Bouxsein ML, Saito H, Galvin RJ, Kuhstoss SA, Thomas CC, Schipani E, Baron R, Bringhurst FR 
\& Kronenberg HM. Suppression of Wht signaling by Dkk1 attenuates PTH-mediated stromal cell response and new bone formation. Cell Metabolism 201011 161-171. (doi:10.1016/j. cmet.2009.12.007)

59 Bodine PV, Billiard J, Moran RA, Ponce-de-Leon H, McLarney S, Mangine A, Scrimo MJ, Bhat RA, Stauffer B, Green J, Stein GS, Lian JB \& Komm BS. The Wnt antagonist secreted frizzled-related protein-1 controls osteoblast and osteocyte apoptosis. Journal of Cellular Biochemistry 200596 1212-1230. (doi:10.1002/jcb. 20599)

60 Yao W, Cheng Z, Shahnazari M, Dai W, Johnson ML \& Lane NE. Overexpression of secreted frizzled-related protein 1 inhibits bone formation and attenuates PTH bone anabolic effects. Journal of Bone and Mineral Research 201025 190-199. (doi:10.1359/ jbmr.090719)

61 Walker EC, McGregor NE, Poulton IJ, Solano M, Pompolo S, Fernandes TJ, Constable MJ, Nicholson GC, Zhang JG, Nicola NA, Gillespie MT, Martin TJ \& Sims NA. Oncostatin M promotes bone formation independently of resorption when signaling through leukemia inhibitory factor receptor in mice. Journal of Clinical Investigation 2010120 582-592. (doi:10.1172/JCI40568)

62 Yadav VK, Balaji S, Suresh PS, Liu XS, Lu X, Li Z, Guo XE, Mann JJ, Balapure AK, Gershon MD, Medhamurthy R, Vidal M, Karsenty G \& Ducy P. Pharmacological inhibition of gut-derived serotonin synthesis is a potential bone anabolic treatment for osteoporosis. Nature Medicine 201016 308-312. (doi:10.1038/ nm.2098)

63 Yadav VK, Ryu JH, Suda N, Tanaka KF, Gingrich JA, Schutz G, Glorieux FH, Chiang CY, Zajac JD, Insogna KL, Mann JJ, Hen R, Ducy P \& Karsenty G. Lrp 5 controls bone formation by inhibiting serotonin synthesis in the duodenum. Cell $2008135825-837$. (doi:10.1016/j.cell.2008.09.059)

64 Warden SJ, Robling AG, Haney EM, Turner CH \& Bliziotes MM. The emerging role of serotonin (5-hydroxytryptamine) in the skeleton and its mediation of the skeletal effects of low-density lipoprotein receptor-related protein 5 (LRP5). Bone $2010 \mathbf{4 6}$ 4-12. (doi:10.1016/j.bone.2009.06.029)

65 Mundy G, Garrett R, Harris S, Chan J, Chen D, Rossini G, Boyce B, Zhao M \& Gutierrez G. Stimulation of bone formation in vitro and in rodents by statins. Science 1999286 1946-1949. (doi:10. 1126/science.286.5446.1946)

66 Maeda T, Kawane T \& Horiuchi N. Statins augment vascular endothelial growth factor expression in osteoblastic cells via inhibition of protein prenylation. Endocrinology $2003 \mathbf{1 4 4}$ 681-692. (doi:10.1210/en.2002-220682)

67 Skoglund B, Forslund C \& Aspenberg P. Simvastatin improves fracture healing in mice. Journal of Bone and Mineral Research 200217 2004-2008. (doi:10.1359/jbmr.2002.17.11.2004)

68 Chan KA, Andrade SE, Boles M, Buist DS, Chase GA, Donahue JG, Goodman MJ, Gurwitz JH, LaCroix AZ \& Platt R. Inhibitors of hydroxymethylglutaryl-coenzyme A reductase and risk of fracture among older women. Lancet 2000355 2185-2188. (doi:10.1016/S0140-6736(00)02400-4)

69 Wang PS, Solomon DH, Mogun H \& Avorn J. HMG-CoA reductase inhibitors and the risk of hip fractures in elderly patients. Journal of the American Medical Association $2000 \mathbf{2 8 3}$ 3211-3216. (doi:10.1001/jama.283.24.3211)

70 Bauer DC, Mundy GR, Jamal SA, Black DM, Cauley JA, Ensrud KE, van der Klift M \& Pols HA. Use of statins and fracture: results of 4 prospective studies and cumulative metaanalysis of observational studies and controlled trials. Archives of Internal Medicine 2004164 146-152. (doi:10.1001/archinte. 164.2.146)

71 LaCroix AZ, Cauley JA, Pettinger M, Hsia J, Bauer DC, McGowan J, Chen Z, Lewis CE, McNeeley SG, Passaro MD \& Jackson RD. Statin use, clinical fracture, and bone density in postmenopausal women: results from the Women's Health Initiative Observational Study. Annals of Internal Medicine 2003139 97-104.

72 Canalis E, Economides AN \& Gazzerro E. Bone morphogenetic proteins, their antagonists, and the skeleton. Endocrine Reviews 200324 218-235. (doi:10.1210/er.2002-0023)
73 Zhao M, Harris SE, Horn D, Geng Z, Nishimura R, Mundy GR \& Chen D. Bone morphogenetic protein receptor signaling is necessary for normal murine postnatal bone formation. Journal of Cell Biology 2002157 1049-1060. (doi:10.1083/ jcb.200109012)

74 Simic P, Culej JB, Orlic I, Grgurevic L, Draca N, Spaventi R \& Vukicevic S. Systemically administered bone morphogenetic protein- 6 restores bone in aged ovariectomized rats by increasing bone formation and suppressing bone resorption. Journal of Biological Chemistry 2006281 25509-25521. (doi:10.1074/ jbc.M513276200)

75 Janssens K, ten Dijke P, Janssens S \& Van Hul W. Transforming growth factor-betal to the bone. Endocrine Reviews 200526 743-774. (doi:10.1210/er.2004-0001)

76 Kalu DN, Salerno E, Higami Y, Liu CC, Ferraro F, Salih MA \& Arjmandi BH. In vivo effects of transforming growth factor-beta 2 in ovariectomized rats. Bone and Mineral 199322 209-220. (doi:10.1016/S0169-6009(08)80069-4)

77 Ahdjoudj S, Lasmoles F, Holy X, Zerath E \& Marie PJ. Transforming growth factor beta 2 inhibits adipocyte differentiation induced by skeletal unloading in rat bone marrow stroma. Journal of Bone and Mineral Research 200217 668-677. (doi:10. 1359/jbmr.2002.17.4.668)

78 Machwate M, Zerath E, Holy X, Hott M, Godet D, Lomri A \& Marie PJ. Systemic administration of transforming growth factorbeta 2 prevents the impaired bone formation and osteopenia induced by unloading in rats. Journal of Clinical Investigation 1995 96 1245-1253. (doi:10.1172/JCI118158)

79 Nicks KM, Perrien DS, Akel NS, Suva LJ \& Gaddy D. Regulation of osteoblastogenesis and osteoclastogenesis by the other reproductive hormones, activin and inhibin. Molecular and Cellular Endocrinology 2009310 11-20. (doi:10.1016/j.mce.2009.07.001)

80 Perrien DS, Akel NS, Edwards PK, Carver AA, Bendre MS, Swain FL, Skinner RA, Hogue WR, Nicks KM, Pierson TM, Suva LJ \& Gaddy D. Inhibin A is an endocrine stimulator of bone mass and strength. Endocrinology 2007148 1654-1665. (doi:10.1210/en.2006-0848)

81 Eijken M, Swagemakers S, Koedam M, Steenbergen C, Derkx P, Uitterlinden AG, van der Spek PJ, Visser JA, de Jong FH, Pols HA \& van Leeuwen JP. The activin A-follistatin system: potent regulator of human extracellular matrix mineralization. FASEB Journal 200721 2949-2960. (doi:10.1096/fj.07-8080com)

82 Lotinun S, Pearsall RS, Davies MV, Marvell TH, Monnell TE, Ucran J, Fajardo RJ, Kumar R, Underwood KW, Seehra J, Bouxsein ML \& Baron R. A soluble activin receptor type IIA fusion protein (ACE-011) increases bone mass via a dual anabolic-antiresorptive effect in cynomolgus monkeys. Bone 201046 1082-1088. (doi:10.1016/j.bone.2010.01.370)

83 Pearsall RS, Canalis E, Cornwall-Brady M, Underwood KW, Haigis B, Ucran J, Kumar R, Pobre E, Grinberg A, Werner ED, Glatt V, Stadmeyer L, Smith D, Seehra J \& Bouxsein ML. A soluble activin type IIA receptor induces bone formation and improves skeletal integrity. PNAS 2008105 7082-7087. (doi:10.1073/ pnas.0711263105)

84 Hamrick MW. A Role for myokines in muscle-bone interactions. Exercise \& Sport Sciences Reviews 201139 43-47. (doi:10.1097/ JES.0b013e318201f601)

85 Hamrick MW, Shi X, Zhang W, Pennington C, Thakore H, Haque M, Kang B, Isales CM, Fulzele S \& Wenger KH. Loss of myostatin (GDF8) function increases osteogenic differentiation of bone marrow-derived mesenchymal stem cells but the osteogenic effect is ablated with unloading. Bone 200740 1544-1553. (doi:10.1016/j.bone.2007.02.012)

86 Kratchmarova I, Blagoev B, Haack-Sorensen M, Kassem M \& Mann M. Mechanism of divergent growth factor effects in mesenchymal stem cell differentiation. Science $2005 \mathbf{3 0 8}$ 1472-1477. (doi:10.1126/science.1107627)

87 Platt MO, Roman AJ, Wells A, Lauffenburger DA \& Griffith LG. Sustained epidermal growth factor receptor levels and activation 
by tethered ligand binding enhances osteogenic differentiation of multi-potent marrow stromal cells. Journal of Cellular Physiology 2009221 306-317. (doi:10.1002/jcp.21854)

88 Marie PJ, Hott M \& Perheentupa J. Effects of epidermal growth factor on bone formation and resorption in vivo. American Journal of Physiology 1990258 E275-E281.

89 Mitlak BH, Finkelman RD, Hill EL, Li J, Martin B, Smith T, D'Andrea M, Antoniades HN \& Lynch SE. The effect of systemically administered PDGF-BB on the rodent skeleton. Journal of Bone and Mineral Research 199611 238-247. (doi:10. 1002/jbmr.5650110213)

90 Marie PJ. Fibroblast growth factor signaling controlling osteoblast differentiation. Gene 2003316 23-32. (doi:10.1016/ S0378-1119(03)00748-0)

91 Dunstan CR, Boyce R, Boyce BF, Garrett IR, Izbicka E, Burgess WH \& Mundy GR. Systemic administration of acidic fibroblast growth factor (FGF-1) prevents bone loss and increases new bone formation in ovariectomized rats. Journal of Bone and Mineral Research 199914 953-959. (doi:10.1359/jbmr.1999. 14.6.953)

92 Yao W, Hadi T, Jiang Y, Lotz J, Wronski TJ \& Lane NE. Basic fibroblast growth factor improves trabecular bone connectivity and bone strength in the lumbar vertebral body of osteopenic rats. Osteoporosis International 200516 1939-1947. (doi:10. 1007/s00198-005-1969-2)

93 Maes C, Goossens S, Bartunkova S, Drogat B, Coenegrachts L, Stockmans I, Moermans K, Nyabi O, Haigh K, Naessens M, Haenebalcke L, Tuckermann JP, Tjwa M, Carmeliet P, Mandic V, David JP, Behrens A, Nagy A, Carmeliet G \& Haigh JJ. Increased skeletal VEGF enhances beta-catenin activity and results in excessively ossified bones. EMBO Journal 201029 424-441. (doi:10.1038/emboj.2009.361)

94 Rosen CJ \& Bilezikian JP. Clinical review 123: anabolic therapy for osteoporosis. Journal of Clinical Endocrinology and Metabolism 200186 957-964. (doi:10.1210/jc.86.3.957)

95 Giustina A, Mazziotti G \& Canalis E. Growth hormone, insulinlike growth factors, and the skeleton. Endocrine Reviews 200829 535-559. (doi:10.1210/er.2007-0036)

96 Kveiborg M, Flyvbjerg A, Rattan SI \& Kassem M. Changes in the insulin-like growth factor-system may contribute to in vitro age-related impaired osteoblast functions. Experimental Gerontology 200035 1061-1074. (doi:10.1016/S0531-5565 (00)00125-X)

97 Langlois JA, Rosen CJ, Visser M, Hannan MT, Harris T, Wilson PW \& Kiel DP. Association between insulin-like growth factor I and bone mineral density in older women and men: the Framingham Heart Study. Journal of Clinical Endocrinology and Metabolism 199883 4257-4262. (doi:10.1210/jc.83.12.4257)

98 Boonen S, Mohan S, Dequeker J, Aerssens J, Vanderschueren D, Verbeke G, Broos P, Bouillon R \& Baylink DJ. Down-regulation of the serum stimulatory components of the insulin-like growth factor (IGF) system (IGF-I, IGF-II, IGF binding protein [BP]-3, and IGFBP-5) in age-related (type II) femoral neck osteoporosis. Journal of Bone and Mineral Research 199914 2150-2158. (doi:10.1359/jbmr.1999.14.12.2150)

99 Yamaguchi T, Kanatani M, Yamauchi M, Kaji H, Sugishita T, Baylink DJ, Mohan S, Chihara K \& Sugimoto T. Serum levels of insulin-like growth factor (IGF); IGF-binding proteins-3, -4, and -5; and their relationships to bone mineral density and the risk of vertebral fractures in postmenopausal women. Calcified Tissue International $2006 \mathbf{7 8}$ 18-24. (doi:10.1007/s00223-005-0163-z)

100 Amin S, Riggs BL, Melton LJ III, Achenbach SJ, Atkinson EJ \& Khosla S. High serum IGFBP-2 is predictive of increased bone turnover in aging men and women. Journal of Bone and Mineral Research 200722 799-807. (doi:10.1359/jbmr.070306)

101 Kassem M, Blum W, Ristelli J, Mosekilde L \& Eriksen EF. Growth hormone stimulates proliferation and differentiation of normal human osteoblast-like cells in vitro. Calcified Tissue International 199352 222-226. (doi:10.1007/BF00298723)
102 DiGirolamo DJ, Mukherjee A, Fulzele K, Gan Y, Cao X, Frank SJ \& Clemens TL. Mode of growth hormone action in osteoblasts. Journal of Biological Chemistry 2007282 31666-31674. (doi:10. 1074/jbc.M705219200)

103 Zhang M, Xuan S, Bouxsein ML, von Stechow D, Akeno N, Faugere MC, Malluche H, Zhao G, Rosen CJ, Efstratiadis A \& Clemens TL. Osteoblast-specific knockout of the insulin-like growth factor (IGF) receptor gene reveals an essential role of IGF signaling in bone matrix mineralization. Journal of Biological Chemistry 2002277 44005-44012. (doi:10.1074/jbc.M208 265200)

104 Zhao G, Monier-Faugere MC, Langub MC, Geng Z, Nakayama T, Pike JW, Chernausek SD, Rosen CJ, Donahue LR, Malluche HH, Fagin JA \& Clemens TL. Targeted overexpression of insulin-like growth factor I to osteoblasts of transgenic mice: increased trabecular bone volume without increased osteoblast proliferation. Endocrinology 2000141 2674-2682. (doi:10.1210/en. 141.7.2674)

105 Yakar S, Canalis E, Sun H, Mejia W, Kawashima Y, Nasser P, Courtland HW, Williams V, Bouxsein M, Rosen C \& Jepsen KJ. Serum IGF-1 determines skeletal strength by regulating subperiosteal expansion and trait interactions. Journal of Bone and Mineral Research 200924 1481-1492. (doi:10.1359/jbmr. 090226)

106 Fowlkes JL, Thrailkill KM, Liu L, Wahl EC, Bunn RC, Cockrell GE, Perrien DS, Aronson J \& Lumpkin CK Jr. Effects of systemic and local administration of recombinant human IGF-I (rhIGF-I) on de novo bone formation in an aged mouse model. Journal of Bone and Mineral Research 200621 1359-1366. (doi:10.1359/jbmr. 060618)

107 Tanaka H, Wakisaka A, Ogasa H, Kawai S \& Liang CT. Effect of IGF-I and PDGF administered in vivo on the expression of osteoblast-related genes in old rats. Journal of Endocrinology 2002 174 63-70. (doi:10.1677/joe.0.1740063)

108 Cao JJ, Kurimoto P, Boudignon B, Rosen C, Lima F \& Halloran BP. Aging impairs IGF-I receptor activation and induces skeletal resistance to IGF-I. Journal of Bone and Mineral Research 200722 1271-1279. (doi:10.1359/jbmr.070506)

109 Conover CA, Johnstone EW, Turner RT, Evans GL, John Ballard FJ, Doran PM \& Khosla S. Subcutaneous administration of insulin-like growth factor (IGF)-II/IGF binding protein-2 complex stimulates bone formation and prevents loss of bone mineral density in a rat model of disuse osteoporosis. Growth Hormone and IGF Research 200212 178-183. (doi:10.1016/ S1096-6374(02)00044-8)

110 Machwate M, Zerath E, Holy X, Pastoureau P \& Marie PJ. Insulinlike growth factor-I increases trabecular bone formation and osteoblastic cell proliferation in unloaded rats. Endocrinology 1994134 1031-1038. (doi:10.1210/en.134.3.1031)

111 Mueller K, Cortesi R, Modrowski D \& Marie PJ. Stimulation of trabecular bone formation by insulin-like growth factor I in adult ovariectomized rats. American Journal of Physiology 1994267 E1-E6.

112 Ghiron LJ, Thompson JL, Holloway L, Hintz RL, Butterfield GE, Hoffman AR \& Marcus R. Effects of recombinant insulinlike growth factor-I and growth hormone on bone turnover in elderly women. Journal of Bone and Mineral Research 199510 1844-1852. (doi:10.1002/jbmr.5650101203)

113 Liu H, Bravata DM, Olkin I, Nayak S, Roberts B, Garber AM \& Hoffman AR. Systematic review: the safety and efficacy of growth hormone in the healthy elderly. Annals of Internal Medicine 2007 $146104-115$.

114 Rudman D, Feller AG, Nagraj HS, Gergans GA, Lalitha PY, Goldberg AF, Schlenker RA, Cohn L, Rudman IW \& Mattson DE. Effects of human growth hormone in men over 60 years old. New England Journal of Medicine 1990323 1-6. (doi:10.1056/ NEJM199007053230101)

115 Brixen K, Kassem M, Nielsen HK, Loft AG, Flyvbjerg A \& Mosekilde L. Short-term treatment with growth hormone stimulates osteoblastic and osteoclastic activity in osteopenic 
postmenopausal women: a dose response study. Journal of Bone and Mineral Research 199510 1865-1874. (doi:10.1002/jbmr. $5650101205)$

116 Gimble JM, Zvonic S, Floyd ZE, Kassem M \& Nuttall ME. Playing with bone and fat. Journal of Cellular Biochemistry 200698 251-266. (doi:10.1002/jcb.20777)

117 Ozcivici E, Luu YK, Adler B, Oin YX, Rubin J, Judex S \& Rubin CT. Mechanical signals as anabolic agents in bone. Nature Reviews. Rheumatology 20106 50-59. (doi:10.1038/nrrheum.2009.239)

118 Marie PJ \& Fromigue O. Osteogenic differentiation of human marrow-derived mesenchymal stem cells. Regenerative Medicine 20061 539-548. (doi:10.2217/17460751.1.4.539)

119 Rosen CJ, Ackert-Bicknell C, Rodriguez JP \& Pino AM. Marrow fat and the bone microenvironment: developmental, functional, and pathological implications. Critical Reviews in Eukaryotic Gene Expression 200919 109-124.

120 Akune T, Ohba S, Kamekura S, Yamaguchi M, Chung UI, Kubota N, Terauchi Y, Harada Y, Azuma Y, Nakamura K, Kadowaki T \& Kawaguchi H. PPARgamma insufficiency enhances osteogenesis through osteoblast formation from bone marrow progenitors. Journal of Clinical Investigation $2004113846-855$. (doi:10.1172/JCI200419900)

121 Idris AI, Sophocleous A, Landao-Bassonga E, Canals M, Milligan G, Baker D, van't Hof RJ \& Ralston SH. Cannabinoid receptor type 1 protects against age-related osteoporosis by regulating osteoblast and adipocyte differentiation in marrow stromal cells. Cell Metabolism 2009 10 139-147. (doi:10.1016/ j.cmet.2009.07.006)

122 Franceschi C, Bonafe M, Valensin S, Olivieri F, De Luca M, Ottaviani E \& De Benedictis G. Inflamm-aging. An evolutionary perspective on immunosenescence. Annals of the New York Academy of Sciences 2000908 244-254. (doi:10.1111/j.17496632.2000.tb06651.x)

123 Nanes MS. Tumor necrosis factor-alpha: molecular and cellular mechanisms in skeletal pathology. Gene 2003321 1-15. (doi:10.1016/S0378-1119(03)00841-2)

124 Wahl EC, Aronson J, Liu L, Fowlkes JL, Thrailkill KM, Bunn RC, Skinner RA, Miller MJ, Cockrell GE, Clark LM, Ou Y, Isales CM, Badger TM, Ronis MJ, Sims J \& Lumpkin CK. Restoration of regenerative osteoblastogenesis in aged mice: modulation of TNF. Journal of Bone and Mineral Research 201025 114-123. (doi:10. 1359/jbmr.090708)

125 Buckbinder L, Crawford DT, Qi H, Ke HZ, Olson LM, Long KR, Bonnette PC, Baumann AP, Hambor JE, Grasser WA III, Pan LC, Owen TA, Luzzio MJ, Hulford CA, Gebhard DF, Paralkar VM, Simmons HA, Kath JC, Roberts WG, Smock SL, Guzman-Perez A, Brown TA \& Li M. Proline-rich tyrosine kinase 2 regulates osteoprogenitor cells and bone formation, and offers an anabolic treatment approach for osteoporosis. PNAS $2007 \mathbf{1 0 4}$ 10619-10624. (doi:10.1073/pnas.0701421104)

126 Neunaber C, Catala-Lehnen P, Beil FT, Marshall RP, Kanbach V, Baranowsky A, Lehmann W, Streichert T, Ignatius A, Muramatsu T, Schinke T \& Amling M. Increased trabecular bone formation in mice lacking the growth factor midkine. Journal of Bone and Mineral Research 201025 1724-1735. (doi:10.1002/jbmr.75)

127 Shimazaki C, Uchida R, Nakano S, Namura K, Fuchida SI, Okano A, Okamoto M \& Inaba T. High serum bone-specific alkaline phosphatase level after bortezomib-combined therapy in refractory multiple myeloma: possible role of bortezomib on osteoblast differentiation. Leukemia $2005 \quad 19$ 1102-1103. (doi:10.1038/sj.leu.2403758)
128 Garrett IR, Chen D, Gutierrez G, Zhao M, Escobedo A, Rossini G, Harris SE, Gallwitz W, Kim KB, Hu S, Crews CM \& Mundy GR. Selective inhibitors of the osteoblast proteasome stimulate bone formation in vivo and in vitro. Journal of Clinical Investigation 2003 111 1771-1782. (doi:10.1172/JCI16198)

129 Mukherjee S, Raje N, Schoonmaker JA, Liu JC, Hideshima T, Wein MN, Jones DC, Vallet S, Bouxsein ML, Pozzi S, Chhetri S, Seo YD, Aronson JP, Patel C, Fulciniti M, Purton LE, Glimcher LH, Lian JB, Stein G, Anderson KC \& Scadden DT. Pharmacologic targeting of a stem/progenitor population in vivo is associated with enhanced bone regeneration in mice. Journal of Clinical Investigation 2008 118 491-504. (doi:10.1172/JCI33102)

130 Qiang YW, Hu B, Chen Y, Zhong Y, Shi B, Barlogie B \& Shaughnessy JD Jr. Bortezomib induces osteoblast differentiation via Wnt-independent activation of beta-catenin/TCF signaling. Blood 2009113 4319-4330. (doi:10.1182/blood-2008-08174300)

131 Tamma R, Colaianni G, Zhu LL, DiBenedetto A, Greco G, Montemurro G, Patano N, Strippoli M, Vergari R, Mancini L, Colucci S, Grano M, Faccio R, Liu X, Li J, Usmani S, Bachar M, Bab I, Nishimori K, Young LJ, Buettner C, Iqbal J, Sun L, Zaidi M \& Zallone A. Oxytocin is an anabolic bone hormone. PNAS 2009 106 7149-7154. (doi:10.1073/pnas.0901890106)

132 Elabd C, Basillais A, Beaupied H, Breuil V, Wagner N, Scheideler M, Zaragosi LE, Massiera F, Lemichez E, Trajanoski Z, Carle G, Euller-Ziegler L, Ailhaud G, Benhamou CL, Dani C \& Amri EZ. Oxytocin controls differentiation of human mesenchymal stem cells and reverses osteoporosis. Stem Cells $20082 \mathbf{6}$ 2399-2407. (doi:10.1634/stemcells.2008-0127)

133 Manolagas SC. From estrogen-centric to aging and oxidative stress: a revised perspective of the pathogenesis of osteoporosis. Endocrine Reviews 201031 266-300. (doi:10.1210/er.20090024)

134 Boily G, Seifert EL, Bevilacqua L, He XH, Sabourin G, Estey C, Moffat C, Crawford S, Saliba S, Jardine K, Xuan J, Evans M, Harper ME \& McBurney MW. SirT1 regulates energy metabolism and response to caloric restriction in mice. PLoS ONE 20083 e1759. (doi:10.1371/journal.pone.0001759)

135 Pearson KJ, Baur JA, Lewis KN, Peshkin L, Price NL, Labinskyy N, Swindell WR, Kamara D, Minor RK, Perez E, Jamieson HA Zhang Y, Dunn SR, Sharma K, Pleshko N, Woollett LA, Csiszar A, Ikeno Y, Le Couteur D, Elliott PJ, Becker KG, Navas P, Ingram DK, Wolf NS, Ungvari Z, Sinclair DA \& de Cabo R. Resveratrol delays age-related deterioration and mimics transcriptional aspects of dietary restriction without extending life span. Cell Metabolism 20088 157-168. (doi:10.1016/j.cmet.2008.06.011)

136 Boissy P, Andersen TL, Abdallah BM, Kassem M, Plesner T \& Delaisse JM. Resveratrol inhibits myeloma cell growth, prevents osteoclast formation, and promotes osteoblast differentiation. Cancer Research 2005 65 9943-9952. (doi:10.1158/00085472.CAN-05-0651)

137 Backesjo CM, Li Y, Lindgren U \& Haldosen LA. Activation of Sirt1 decreases adipocyte formation during osteoblast differentiation of mesenchymal stem cells. Cells Tissues Organs 2009189 93-97. (doi:10.1159/000151744)

Received 31 March 2011

Accepted 27 April 2011 